\title{
Shifts in attack behavior of an important kelp forest predator within marine reserves
}

\author{
J. S. Berriman ${ }^{1,2}$, M. C. Kay ${ }^{3}$, D. C. Reed ${ }^{4}$, A. Rassweiler ${ }^{4}$, D. A. Goldstein ${ }^{1}$, \\ W. G. Wright ${ }^{1, *}$
}

\begin{abstract}
${ }^{1}$ Faculty of Biological Sciences, Chapman University, One University Dr., Orange, CA 92866, USA ${ }^{2}$ Biological Sciences, CSU Los Angeles, 5151 State University Drive, Los Angeles CA 90032, USA

${ }^{3}$ Department of Biological Sciences, Santa Barbara City College, Santa Barbara, CA 93109, USA ${ }^{4}$ Marine Science Institute, University of California, Santa Barbara, CA 93106, USA
\end{abstract}

\begin{abstract}
Marine reserves have become increasingly valuable tools with which to manage ecosystems. These reserves consistently restore populations of top predators, often reducing availability of their favored prey. We hypothesized that such prey reduction in reserves causes protected predators to alter their attack behavior to include less palatable prey, potentially amplifying top-down effects on community structure. To test this hypothesis, we presented the relatively unpalatable sea hare Aplysia californica to freely foraging spiny lobsters Panulirus interruptus in 4 marine no-take reserves, each paired with an adjacent fished area. We found that lobsters only attacked sea hares inside reserves, where lobster density was significantly greater than that of the adjacent fished areas. Attacks on otherwise unpalatable prey exclusively in no-take reserves was likely caused by increased hunger, since in the laboratory only food-deprived lobsters attacked sea hares. These findings are the first to suggest that management involving no-take reserves may have unintended consequences on community structure that result from behavioral changes in key predators in the face of increased competition for food. We suspect that these effects may become more widely detected as reserves across the globe grow older and are researched further.
\end{abstract}

KEY WORDS: Reserve effects - Density - Attack behavior - Predator-prey interactions . Panulirus interruptus · Aplysia californica · Diet · Foraging · Marine Protected Area

\section{INTRODUCTION}

Scientific study of marine reserves has evolved rapidly in recent decades as reserves have proliferated around the globe (Lester et al. 2009, Gaines et al. 2010). Early empirical work demonstrated that reserve protection directly increased the density of harvested target species (Davis \& Doldrill 1980, Cole et al. 1990). In addition, more recent studies have identified strong indirect effects on community structure, mediated by the abundant protected predators (Shears \& Babcock 2003, Sale et al. 2005, Babcock et al. 2010, Aburto-Oropeza et al. 2011). Virtually all research in this area has focused on numerical effects; field work has typically measured aggregate disappearance rates of preferred prey (e.g. Shears \& Babcock 2002, Pederson \& Johnson 2006, Guidetti \& Dulcic 2007) and multispecies models assume constant attack rates by predators (e.g. Kellner et al. 2010). The possibility of a significant change in predator foraging behavior in reserves has not been investigated.

In marine reserves where increased predator abundance reduces the availability of preferred prey items, optimal diet theory suggests that predators should increase the range of acceptable prey items to include less desirable species (Pyke et al. 1977, Sih \& Christensen 2001, Svanbäck \& Bolnick 2007). If true, 
then this hypothesized change in behavior could have potentially large, and otherwise unintended, consequences for community structure. In many systems, the prey species with the greatest potential to alter community structure are those that can reach very high densities because they are either not favored due to their low nutritional value (Stewart \& Konar 2012), or are unpalatable due to chemical defense (Eckert 2007). If predators change their attack behavior and begin eating such unfavored prey in reserves where preferred prey are depleted, the consequences to community structure would be significant.

The California spiny lobster Panulirus interruptus is an important and heavily fished kelp forest predator. Like most clawless lobsters, it is a generalist predator of benthic invertebrates (Lindberg 1955, Castañeda-Fernandez-de-Lara et al. 2005). Protection by marine reserves in California has been shown to increase the density of lobsters (Iacchei et al. 2005, Kay et al. 2012a,b) and reduce the density of sea urchins (Lafferty 2004), which are common lobster prey (Lindberg 1955, Tegner \& Dayton 1981, Zimmer-Faust \& Case 1982, Tegner \& Levin 1983). Similar reserve effects on densities of lobsters and sea urchins have been reported elsewhere in the world (Shears \& Babcock 2002, Pederson \& Johnson 2006, Ling et al. 2009).

In the present study, we examined whether the protection afforded by marine reserves caused the California spiny lobster to alter its attack behavior to include unpalatable prey. To do this, we first verified the effects of reserves on the abundance of $P$. interruptus and sea urchins by measuring their densities in 4 marine no take reserves, each paired with an adjacent fished area. Previous comparisons of lobster and urchin densities inside versus outside reserves have shown predation by spiny lobsters to have a significant impact on urchin populations (Shears \& Babcock 2002, Lafferty 2004, Pederson \& Johnson 2006, Ling et al. 2009). We then assessed whether predator attack behavior varied with reserve status by experimentally offering individuals of a chemically defended prey species, the California sea hare Aplysia californica, to foraging California spiny lobsters at the paired protected and unprotected sites. Individuals of $A$. californica deploy active (i.e. ink and opaline; Kicklighter et al. 2005, Derby \& Aggio 2011) as well as passive (Takagi et al. 2010) chemical defenses to make them effectively unpalatable to most predators (see review by Carefoot 1987). If indeed lobsters attacked sea hares only inside reserves, then this would (1) be consis- tent with optimal diet theory, (2) constitute previously unreported evidence that reserves change attack behavior of protected predators, and (3) highlight the need to consider changes in predator behavior when assessing the ecological consequences of marine protected areas.

\section{MATERIALS AND METHODS}

We chose 4 rocky-reef sites (Fig. 1) inside different aged reserves where lobsters have been protected since (from southeast to northwest) 1988 (Big Fisherman Cove, Catalina Island no-take reserve), 1980 (Lulu Cove, Catalina Island invertebrate no-take reserve), 1978 (Cathedral Cove, Anacapa Island notake reserve), and 2003 (Cavern Point, Santa Cruz

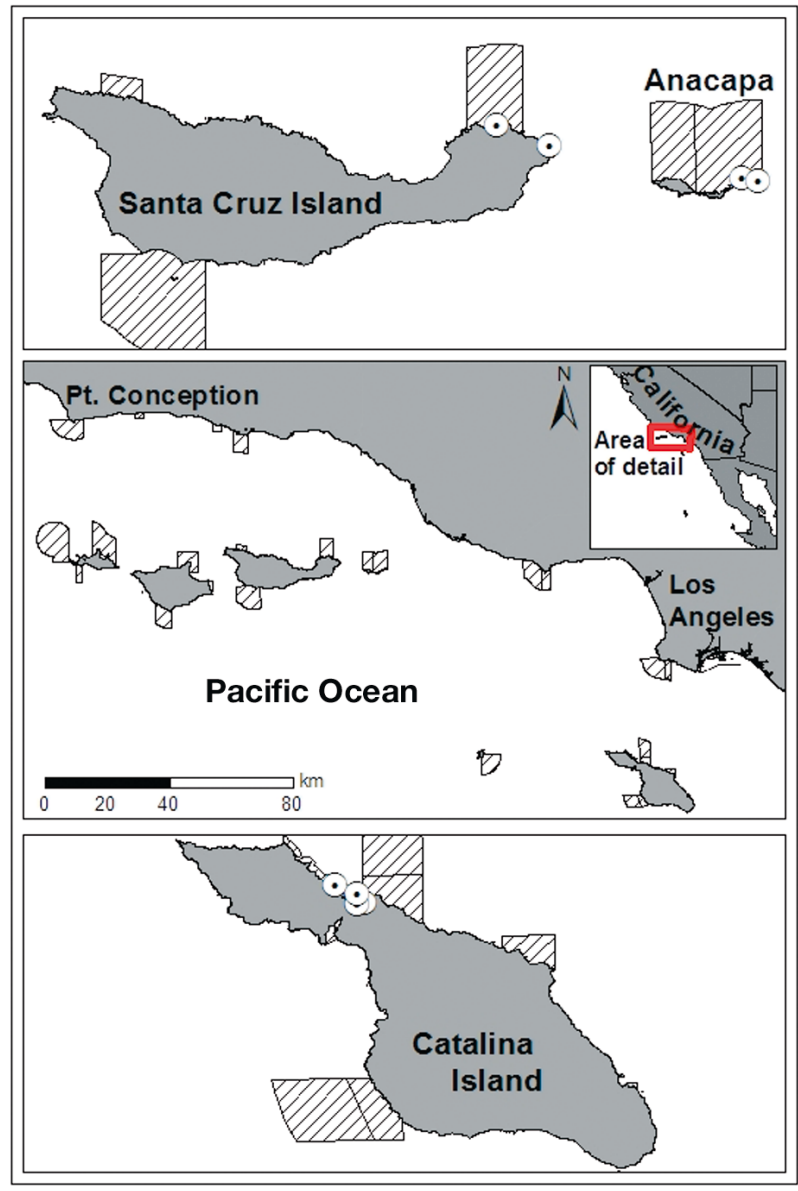

Fig. 1. Study area showing the Marine Protected Areas (MPAs, hatched areas) of the southern California bight. Circled dots indicate reserve sites and adjacent fished sites used in the present study for Santa Cruz Island $\left(34.052^{\circ} \mathrm{N}\right.$, $\left.119.567^{\circ} \mathrm{W}\right)$, Anacapa Island $\left(34.015^{\circ} \mathrm{N}, 119.372^{\circ} \mathrm{W}\right)$, and Catalina Island $\left(33.445^{\circ} \mathrm{N}, 118.486^{\circ} \mathrm{W}\right)$; invertebrate notake reserve, to the west of the MPA, $33.454^{\circ} \mathrm{N}, 118.505^{\circ} \mathrm{W}$ ) 
Island no-take reserve). We paired each protected reef with an adjacent fished reef outside the reserve.

We used SCUBA to collect population density data for spiny lobsters and 3 common species of sea urchins (Centrostephanus coronatus, Mesocentrotus franciscanus, and Strongylocentrotus purpuratus) from reserves and adjacent fished areas at Catalina Island in the summer and early autumn of 2012. Data for Anacapa Island and Santa Cruz Island reserves and adjacent fished areas were obtained from the US National Park Service, who used similar methods during summer and early autumn of 2011 (Kushner et al. 2013). All surveys were conducted before the start of California's annual lobster fishing season. Lobster density was measured at all sites in $20 \times 3 \mathrm{~m}$ plots located transversely across a single $100 \mathrm{~m}$ long transect $\left(3\right.$ to $8 \mathrm{~m}$ depth, $\mathrm{n}=11$ or 12 plots transect ${ }^{-1}$ ). Densities of sea urchins were measured in $2 \mathrm{~m}^{2}$ quadrats spaced every $10 \mathrm{~m}$ along a $100 \mathrm{~m}$ transect ( 3 to $8 \mathrm{~m}$ depth, $\mathrm{n}=12$ quadrats transect ${ }^{-1}$, Anacapa and Santa Cruz Islands, National Park Service) or in $1 \mathrm{~m}^{2}$ quadrats spaced every $5 \mathrm{~m}$ along a 100 to $150 \mathrm{~m}$ transect ( 3 to $8 \mathrm{~m}$ depth, $\mathrm{n}=21$ to 32 quadrats transect $^{-1}$, Catalina Island).

To observe the propensity for lobster to attack unpalatable prey, we presented individuals of the California sea hare Aplysia californica to freely foraging lobsters at each of the 4 site pairs in autumn 2009 and summer and autumn 2012. Sea hares were collected from non-reserve areas at Catalina Island or Palos Verdes Peninsula on the mainland (ca. $35 \mathrm{~km}$ northeast of Catalina Island; $33.7742^{\circ} \mathrm{N}, 118.4306^{\circ} \mathrm{W}$ ), and were maintained in running seawater before being presented to lobsters in the field. All behavioral observations were performed using SCUBA ( 3 to $12 \mathrm{~m}$ depth) after sunset, when the nocturnal lobsters forage for food. We used red lights to minimize disturbance to lobsters. Each lobster encountered during a dive was presented with a sea hare by positioning the sea hare anterior to the antennules of the lobster, while avoiding excessive motion (lobsters presented with sea hares were separated by at least $3 \mathrm{~m}$, usually $>10 \mathrm{~m}$; details on the number of dives and number of presentations per dive are summarized in the Appendix). A lobster's behavior was scored as 'attack' if it grasped and moved the sea hare to its mouth and manipulated it there for a minimum of $10 \mathrm{~s}$. Usually, the lobster either aggressively grasped and bit the sea hare (attack), or alternatively showed no interest, often batting it away with its antennae. Rarely (ca. 10\% of observations), lobsters grasped the sea hare for a few seconds before releasing it and moving away. For each dive, we calculated the percentage of presentations that elicited attack behavior.

To investigate whether attack is commonly followed by consumption, we observed 3 of these attacks for more than $5 \mathrm{~min}$. We also performed an enclosure experiment in the field that tested whether acclimated sea hares were vulnerable to consumption. In 10 separate experiments, we placed 5 sea hares into a mesh enclosure $(2 \times 1 \times 1 \mathrm{~m})$ for $24 \mathrm{~h}$, then added a reserve-caught lobster which had demonstrated its willingness to attack a presented sea hare. In 7 control experiments, we placed sea hares into enclosures lacking lobsters. We compared the disappearance of sea hares from these 2 treatments with a Fisher's exact test.

In the laboratory, we tested whether hunger led to a higher probability of lobsters attacking unpalatable prey. We captured lobsters by hand at Big Fisherman Cove reserve and the adjacent fished area after presenting them with a sea hare. Captured lobsters were placed in buckets of seawater and transported within $2 \mathrm{~h}$ to large (2 m diameter, $1.5 \mathrm{~m}$ deep) tanks supplied with running seawater at the Wrigley Marine Science Center. There, we deprived each lobster of food, and presented it with a live sea hare every evening until the lobster attacked the sea hare. Presentation of sea hares and scoring of lobster behavior (e.g. willingness to attack) were performed in the same manner as in the field. Differences between the treatments in the number of days elapsed before an attack were evaluated with a Kruskal-Wallis test.

Lobsters in the adjacent fished areas of our study experience recreational fishing by hand, hoop nets, and traps (Neilson et al. 2009, Kay et al. 2012a,b). As a result, it is possible that lobsters in fished areas are more wary of humans than lobsters living in reserves, and thus less likely to attack any type of prey offered by divers regardless of palatability. We tested this hypothesis during summer 2013 by presenting pieces of market squid Doryteuthis opalescens, a highly palatable food, to freely foraging lobsters within Big Fisherman Cove reserve and its adjacent fished area following the same protocol used when presenting sea hares. Market squid are seasonally abundant lobster forage at our sites and elsewhere in southern California, where they aggregate to spawn and subsequently die (e.g. Zeidberg et al. 2012).

The effects of protection status and site on the densities of lobsters and sea urchins were separately evaluated using generalized linear models (GLMs; Poisson distributed error, log link). Because reserves were different ages, site was treated as a 
fixed factor. There were 2 levels of protection status (reserve and fished) and 4 sites (Big Fisherman Cove, Lulu Cove, Cathedral Cove and Cavern Point). We tested the effect of protection status on the frequency with which lobsters attacked sea hares in 2 ways. First, we treated each presentation as an independent sample and applied a log linear analysis with site and reserve status as fixed factors. Second, because of potential non-independence of presentations within the same dive, we reanalyzed the data with a more conservative approach, treating dives as independent samples. We used Fisher's exact test to examine differences between reserves and fished areas with respect to the fraction of dives in which at least one attack was observed. All statistical tests were performed in SAS v.9.4 (SAS Institute).

\section{RESULTS}

As has been found in previous research on reserves in the Channel Islands (Lafferty 2004, Iacchei et al. 2005, Kay et al. 2012a,b) the density of lobsters in the present study was consistently higher inside no-take reserves compared to adjacent unprotected fished areas (Fig. 2A). The degree to which lobster densities were significantly higher inside reserves varied among sites (GLM-Poisson, $F_{6,88}=17.20, \mathrm{p}<0.0001$ for the reserve $\times$ site interaction). By contrast, the density of sea urchins inside reserves was much lower ( 0 to $16 \%$, mean \pm SE: $9.5 \pm 2.9 \%, n=4)$ than that in adjacent fished areas (Fig. 2B). The magnitude of the difference in urchin densities inside versus outside reserves also varied among sites (GLMPoisson, $F_{6,135}=335.6, \mathrm{p}<0.0001$ for the reserve $\times$ site interaction).

Lobsters showed no attack behavior on sea hares at any of the fished sites ( $\mathrm{n}=13$ dives; Fig. 3 ), which is consistent with observations that sea hares are rarely if ever eaten by lobsters (Carefoot 1987, D. Stark pers. comm.). By contrast, we consistently observed lobsters attacking sea hares in 3 of the 4 reserves $(22$ of 26 total reserve dives), implying a significant difference in attack rates inside reserves relative to outside (Fisher's exact test, $\mathrm{p}<0.0001$; Fig. 3). A loganalysis of the data, treating each presentation as independent, confirmed this conclusion, indicating a significant effect of reserve status on probability of attack $\left(\chi^{2}=95.6, \mathrm{df}=1, \mathrm{p}<0.0001\right)$ and a significant site effect $\left(\chi^{2}=52.5\right.$, df $\left.=3, p<0.0001\right)$.

In order to assess whether lobsters consumed the sea hares they attacked, we observed 3 individual

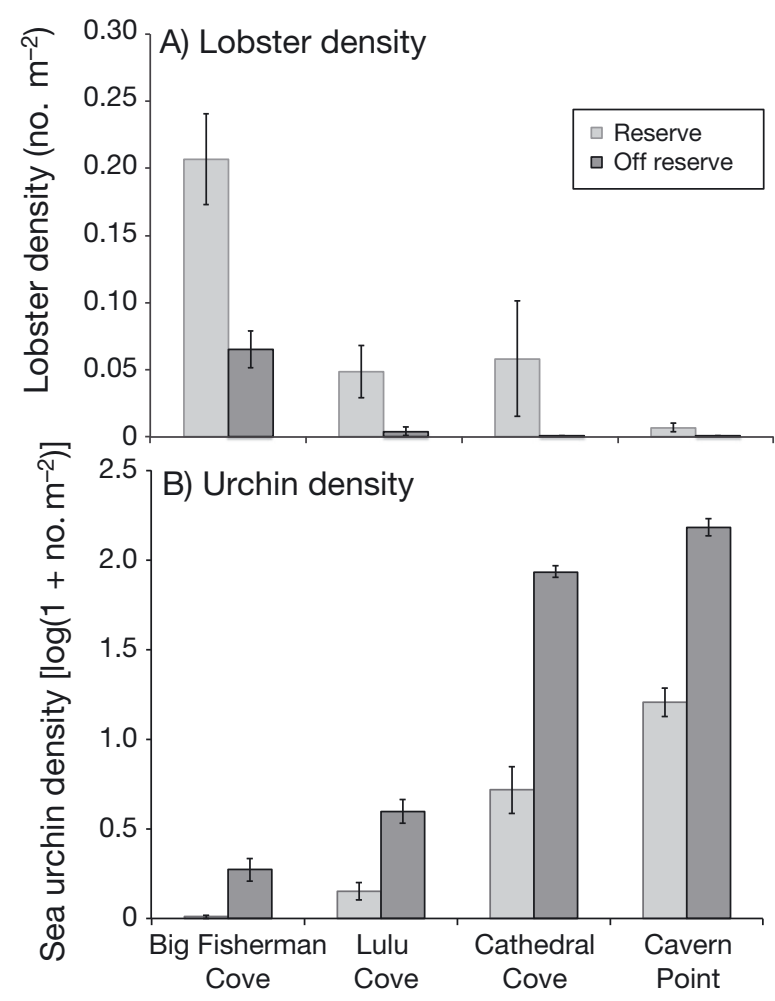

Fig. 2. Mean $( \pm \mathrm{SE})$ densities $(\mathrm{n}=11$ to 12 transects) of $(\mathrm{A})$ lobsters (no. $\mathrm{m}^{-2}$ ) and (B) urchins (densities of Centrostephanus coronatus, Strongylocentrotus purpuratus, and $S$. franciscanus combined; $\log \left[1+\right.$ no. $\left.\left.\mathrm{m}^{-2}\right]\right)$ in 4 different reserves (light bars), compared with density in adjacent fished sites (dark bars), showing that marine reserves have increased lobster and decreased urchin densities

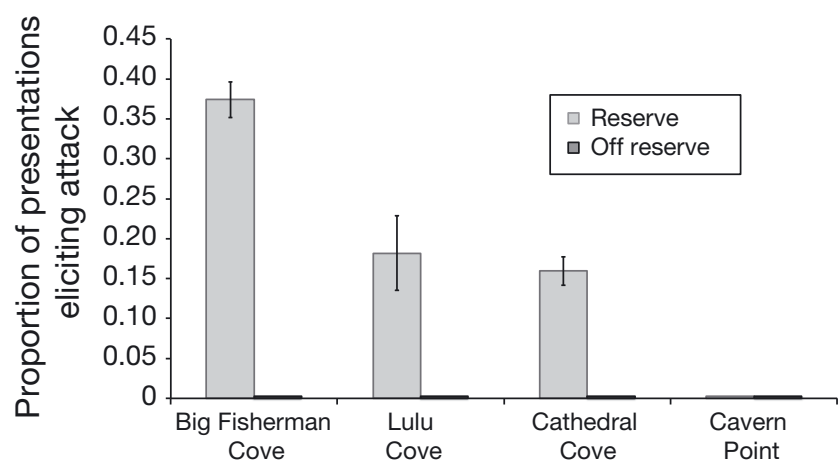

Fig. 3. Mean $( \pm \mathrm{SE}$ ) proportion of presentations ( $n=8$ to 26 presentations dive $^{-1}$ ) eliciting attack behavior for each of 4 reserves (light bars; no. of dives =12, 5, 5, and 4 for Big Fisherman Cove, Lulu Cove, Cathedral Cove and Cavern Point, respectively) and their adjacent fished control sites all showing zero attacks (dark bars, $\mathrm{n}=3,3,4,3$ dives), indicating that lobsters only attacked sea hares in no-take reserves

lobsters after they had dragged their sea hare offering into dens, where each lobster continued to consume its prey. Two of the 3 lobsters eventually retreated deeper into their dens, where they were 
hidden from observation by the diver. The third lobster remained visible. This lobster continued to eat the sea hare for the next $60 \mathrm{~min}$ (when our air supply was exhausted). We were able to retrieve the remains of the sea hare at that time. It was approximately $10 \%$ of the volume prior to attack. The consumption of presented sea hares by lobsters was also supported by the results of the field enclosure experiments, in which sea hares disappeared from 7 of the 10 enclosure trials with lobsters and 0 of 7 trials without lobsters (Fisher's exact test, $\mathrm{p}<0.01$ ).

Significantly, the only reserve in which lobsters did not attack sea hares was the most recently established of the 4 reserves (Cavern Point), which also had by far the lowest lobster densities (0.007 ind. $\mathrm{m}^{-2}$; Fig. 1) and highest urchin densities (38 ind. $\mathrm{m}^{-2}$; Fig. 3). When the behavioral results from this new reserve and its adjacent control site were excluded, 19 out of 19 dives inside reserves showed attack behavior versus 0 attacks in 9 dives at sites outside reserves. Our results suggest that the willingness of lobsters to attack unpalatable prey is increased by their higher densities inside reserves, a supposition supported by the overall high correlation between average attack frequency and the density of lobsters $(\mathrm{r}=0.90, \mathrm{p}=0.0024$; Fig. 4).

Attack rates on market squid, a more palatable food item, were similar in both fished $(67 \pm 4.7 \%$; 24

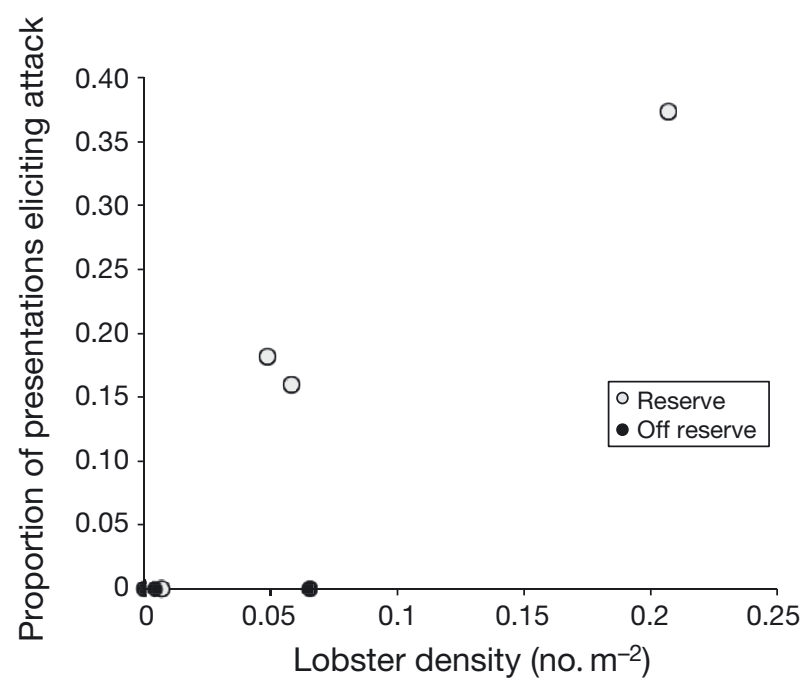

Fig. 4. Proportion of sea hare presentations that elicited an attack versus lobster density (no. $\mathrm{m}^{-2} ; \mathrm{r}=0.90, \mathrm{p}=0.0024$ ). Plotted values on the $y$-axis are site means of attack calculated from 4 to 12 dives site ${ }^{-1}$ (light symbols: reserves; dark symbols: adjacent fished areas); values on $x$-axis are site average density presentations during 3 dives) and reserve areas (72 \pm $5.5 \%$; 30 presentations during 4 dives). They were also much greater than attack rates on sea hares $(0$ and $37 \%$ in fished and reserve areas, respectively; Fig. 3, Big Fisherman Cove). These observations further support the idea that palatability of the prey is a critical determinant of the effects of reserves on predator attack behavior.

In the laboratory, we found that most lobsters did not attack sea hares until they had experienced several days of food deprivation. Furthermore, the propensity for lobsters to attack sea hares in the lab depended on the reserve status and initial attack behavior observed in the field. Lobsters caught in fished areas that did not attack sea hares in the field delayed for $8.3 \pm 1.3 \mathrm{~d}(\mathrm{n}=4)$ before their first attack behavior on sea hares in the laboratory. By contrast, reserve-caught lobsters that attacked sea hares in the field attacked sea hares in the laboratory within an average of only $2.3 \pm 0.5 \mathrm{~d}(\mathrm{n}=7)$. Finally, reserve-caught lobsters that failed to attack sea hares in the field delayed an intermediate number of days $6.3 \pm 0.3 \mathrm{~d}(\mathrm{n}=3)$ before attacking a sea hare in the lab. The time before consumption was significantly different across the 3 groups (Kruskal-Wallis test, $\chi^{2}=9.7, \mathrm{df}=2, \mathrm{p}<0.0003$ ). If treated as 2 groups (reserve-caught and off-reserve lobsters), time until first attack behavior was still significantly different (Kruskal-Wallis test, $\chi^{2}=5.9$, $\mathrm{df}=1, \mathrm{p}=0.0154$ ).

\section{DISCUSSION}

Our observations indicate that the protection afforded by marine reserves leads to higher densities of hungrier lobsters, which causes them to attack otherwise unpalatable prey. The fact that we observed no lobster attacks on sea hares outside reserves reaffirms their unpalatability, as originally demonstrated in laboratory studies (Carefoot 1987, Kicklighter et al. 2005, Derby \& Aggio 2011). Chemical defenses, both passively sequestered in the body wall, and actively secreted in response to a predatory attack are known to deter lobster feeding (Kicklighter et al. 2005, Derby \& Aggio 2011). Our observations indicate that despite these chemical defenses, sea hares were attacked and consumed to some degree by hungry lobsters inside reserves. Our finding that food deprivation in the laboratory eventually causes lobsters collected outside reserves to attack sea hares implies that hunger is the proximate cause of this shift in attack behavior. 
The differences that we observed between reserves and fished areas in the propensity of lobsters to attack unpalatable sea hares cannot be explained by differences in the skittishness of lobsters because reserve and fished-area lobsters were similar in their willingness to attack palatable food offered by divers. The hunger hypothesis is further supported by our laboratory observations that the willingness of lobsters to attack sea hares increased with length of food deprivation, and that a shorter period of deprivation was required to induce attack if lobsters were captured inside the reserve. Patterns of abundance of one class of known prey item (urchins) also support the hunger hypothesis. However, lobster density is clearly not the only driver of lobster behavior, as evidenced by different attack rates observed at similar densities of lobsters (e.g. Big Fisherman Cove off-reserve versus Cathedral Cove on-reserve). Although we do not understand all drivers of attack behavior, the clear patterns between paired reserve and off-reserve sites strongly supports reserve protection as one important driver.

The extent to which spiny lobster behavior has been altered by changes in the densities and size structure of their predators (Pondella \& Allen 2008) is unknown. Nonetheless, it is unlikely that such changes accounted for the differences in lobster behavior that we observed. Large predatory fish such as giant sea bass Stereolepis gigas are universally rare in southern California, and other species that potentially feed on lobsters such as the California sheephead Semicossyphus pulcher and kelp bass Paralabrax clathratus tend to be larger and more abundant inside reserves (Tetreault \& Ambrose 2007, Loflen \& Hovel 2010). Higher densities and larger sizes of these potential predators inside reserves should, if anything, have made reserve lobsters more skittish and less likely to attack the sea hares presented by divers. As noted above, we did not find this to be true.

Studies of foraging behavior of spiny lobsters from California (Withy-Allen \& Hovel 2013) as well as other palinurids (Green et al. 2013, Steyn \& Schleyer 2011) suggest that lobsters are relatively mobile, moving hundreds of meters per night as they forage for food. However, these studies also show that spiny lobsters have high site fidelity and generally stay within a 1 ha area for weeks to months. Furthermore, tagging studies have shown that movement of spiny lobsters into and out of reserves is relatively uncommon (Kay et al. 2012a). Thus, it is reasonable to assume that lobsters inside reserves will remain there long enough to experience the high densities of conspecifics and relatively depleted food supply, thereby leading them to broaden the list of species they will attack for food.

The shift in predatory behavior within marine reserves described here has yet to be reported for any taxa. Our discovery of this effect in the California spiny lobster is noteworthy because the effects of reserves on the density and size of spiny lobsters are well described (Lafferty 2004, Iacchei et al. 2005, Kay et al. 2012a,b). In many instances, spiny lobsters have served as model organisms for marine reserve research. For example, spiny lobsters were the focus of early empirical studies profiling the direct effects of reserves on fished species (e.g. Davis \& Doldrill 1980, Cole et al. 1990), and they continue to provide insights into indirect effects such as changes in community structure due to trophic cascades (Babcock et al. 2010), disease dynamics among prey species (Lafferty 2004), and increased fishery yield due to reserves (Goñi et al. 2010). The finding of the present study is significant because in the absence of predator control some species of unpalatable prey are known to form dense aggregations that exclude more palatable species (e.g. Eckert 2007, Rassweiler et al. 2010). Our findings suggest that the protection from fishing afforded to top predators by no-take reserves may indirectly alter community dynamics by reducing opportunities for these unpalatable prey to dominate in the face of predatory behavior that is absent outside the reserve. Although sea hares are normally found at low densities in our study region $\left(<0.1\right.$ ind. $\mathrm{m}^{-2}$; Kushner et al. 2013) and are not known to have strong effects on the structure of the communities in which they live, they proved to be an effective model species for testing whether reserves cause predators to alter their attack behavior to include unpalatable prey.

There are no previous reports of presentations of the same prey item to predators in protected versus unprotected areas, most likely because presenting prey to predators is usually difficult. Nevertheless, changes in diet are known among protected predators. For example, individuals in established populations of the protected sea otter Enhydra lutris forage on less preferred species once their preferred prey become depleted (Tinker et al. 2008). More generally, predators that have depleted their preferred prey are predicted to broaden their diet (Stephens \& Krebs 1986, Svanbäck \& Bolnick 2007), and observation confirms this supposition (Barkai \& Branch 1988, Stiner 2002, Roth et al. 2007, Svanbäck \& Bolnick 2007, Haley et al. 2011). Importantly, there have been no comparisons of attack behavior of predators inside versus outside reserves on a geographical scale of specific protected areas, and our findings of 
altered predator behavior may apply generally to areas with protected status.

Although our results focused on a single trophic link, the increased willingness of lobsters to attack sea hares inside reserves suggests an overall broadening of this predator's palette of acceptable prey within reserves. Thus, lobsters' increased willingness to attack sea hares is likely to be only one aspect of a general change in behavior generated by increased hunger, with increased attack rates on preferred prey and a willingness to attack prey that would otherwise be ignored. Changes in predator behavior such as these pose a challenge for predicting the effects of marine reserve implementation. In the absence of reserves, interaction strengths can only be estimated from fished populations. If predators have higher per-capita attack rates on some prey species within reserves, then the potential for reserves to produce top-down effects and trigger trophic cascades may be much greater than otherwise anticipated (Strong 1992). More dramatically, reserve protection may create trophic links that are non-existent outside of protected areas, as documented in this study. Furthermore, these 'new' trophic links may well reflect those present before modern fishing began. The consequences of major reorganization of the food web within reserves are potentially far-reaching, as food-web structure can have significant effects on the strength of top-down control, trophic dynamics, and community stability (Dunne et al. 2002, Bascompte et al. 2005). Although consistent with optimal diet theory, this potential for new trophic links has not been considered in the context of marine reserves.

The possibility that predator-prey interaction strengths are altered by reserve protection has important implications for conservation and management. The benefits of marine reserves for conservation are increasingly well documented (Lester et al. 2009). Furthermore, reserve design can strongly affect performance (Rassweiler et al. 2012), and mathematical models (Smith \& Wilen 2003, Gaylord et al. 2005, Rassweiler et al. 2014) are increasingly being used to guide design (White et al. 2013). While a few models of reserve effects have incorporated trophic dynamics (e.g. Kellner et al. 2010), none have accounted for changes in per-capita interaction strengths, such as demonstrated in this study. Incorporating alterations in trophic links resulting from protection status into models used for decision-making should improve the ability of marine reserves to meet their intended goals in conservation and fishery management.
Acknowledgements. We thank G. Smith for logistic support at the WMSC, J. Estes (UC Santa Cruz) for comments on an earlier draft, and the National Science Foundation for financial support (IOS-0721800 to W.G.W., and Santa Barbara Coastal LTER to D.C.R.). We also thank the volunteer divers from UCSB, CSU Monterey, Georgia State University and Chapman University who contributed to this research.

\section{LITERATURE CITED}

Aburto-Oropeza O, Erisman B, Galland GR, MascarenasOsorio I, Sala E, Ezcurra E (2011) Large recovery of fish biomass in a no-take marine reserve. PLoS ONE 6:e23601

Babcock RC, Shears NT, Alcala AC, Barrett NS and others (2010) Decadal trends in marine reserves reveal differential rates of change in direct and indirect effects. Proc Natl Acad Sci USA 107:18256-18261

$>$ Barkai A, Branch GM (1988) Energy requirements for a dense population of rock lobsters, Jasus lalandii: novel importance of unorthodox food sources. Mar Ecol Prog Ser 50:83-96

Bascompte J, Melián C, Sala E (2005) Interaction strength combinations and the overfishing of a marine food web. Proc Natl Acad Sci USA 102:5443-5447

Carefoot TH (1987) Aplysia: its biology and ecology. Oceanogr Mar Biol Annu Rev 25:167-284

Castañeda-Fernandez-de-Lara V, Serviere-Zaragoza E, Hernandez-Vazquez S, Butler MJ (2005) Feeding ecology of juvenile spiny lobster, Panulirus interruptus, on the Pacific coast of Baja California Sur, Mexico. NZ J Mar Freshw Res 39:425-435

Cole RG, Ayling TM, Creese RG (1990) Effects of marine reserve protection at Goat Island, northern New Zealand. NZ J Mar Freshw Res 24:197-210

Davis G, Doldrill J (1980) Marine parks and sanctuaries for spiny lobster fisheries management. Proc Gulf Caribb Fish Inst 32:194-207

> Derby CD, Aggio JF (2011) The neuroecology of chemical defenses. Integr Comp Biol 51:771-780

> Dunne JA, Williams RJ, Martinez ND (2002) Network structure and biodiversity loss in food webs: robustness increases with connectance. Ecol Lett 5:558-567

- Eckert GL (2007) Spatial patchiness in the sea cucumber Pachythyone rubra in the California Channel Islands. J Exp Mar Biol Ecol 348:121-132

> Gaines SD, Lester SE, Grorud-Colvert K, Costello C, Pollnac R (2010) Evolving science of marine reserves: new developments and emerging research frontiers. Proc Natl Acad Sci USA 107:18251-18255

- Gaylord B, Gaines SD, Siegel DA, Carr MH (2005) Marine reserves exploit population structure and life history in potentially improving fisheries yields. Ecol Appl 15: 2180-2191

> Goñi R, Hilborn R, Diaz D, Mallol S, Adlerstein S (2010) Net contribution of spillover from a marine reserve to fishery catches. Mar Ecol Prog Ser 400:233-243

Green BS, Pederson H, Gardner C (2013) Overlap of home ranges of resident and introduced southern rock lobster after translocation. Rev Fish Sci 21:258-266

Guidetti P, Dulcic J (2007) Relationships among predatory fish, sea urchins and barrens in Mediterranean rocky reefs across a latitudinal gradient. Mar Environ Res 63: 168-184 
Haley CN, Blamey LK, Atkinson LJ, Branch GM (2011) Dietary change of the rock lobster Jasus lalandii after an 'invasive' geographic shift: effects of size, density and food availability. Estuar Coast Shelf Sci 93: 160-170

Iacchei M, Robinson P, Miller KA (2005) Direct impacts of commercial and recreational fishing on spiny lobster, Panulirus interruptus, populations at Santa Catalina Island, California, United States. NZ J Mar Freshw Res 39:1201-1214

Kay MC, Lenihan HS, Guenther CM, Wilson JR, Miller CJ, Shrout SW (2012a) Collaborative assessment of California spiny lobster population and fishery responses to a marine reserve network. Ecol Appl 22:322-335

Kay MC, Lenihan HS, Kotchen MJ, Miller CJ (2012b) Effects of marine reserves on California spiny lobster are robust and modified by fine-scale habitat features and distance from reserve borders. Mar Ecol Prog Ser 451:137-150

Kellner JB, Litvin SY, Hastings A, Micheli F, Mumby PJ (2010) Disentangling trophic interactions inside a Caribbean marine reserve. Ecol Appl 20:1979-1992

Kicklighter CE, Shabani S, Johnson PM, Derby CD (2005) Sea hares use novel antipredatory chemical defenses. Curr Biol 15:549-554

Kushner DJ, Rassweiler A, McLaughlin J, Lafferty K (2013) A multi-decade time series of kelp forest community structure at the California Channel Islands. Ecology 94: 2655

Lafferty KD (2004) Fishing for lobsters indirectly increases epidemics in sea urchins. Ecol Appl 14:1566-1573

Lester SE, Halpern BS, Grorud-Colvert K, Lubchenco J and others (2009) Biological effects within no-take marine reserves: a global synthesis. Mar Ecol Prog Ser 384: 33-46

Lindberg RG (1955) Growth, population dynamics, and field behavior in the spiny lobster, Panulirus interruptus (Randall). Univ Calif Publ Zool 59:157-248

> Ling SD, Johnson CR, Frusher SD, Ridgway KR (2009) Overfishing reduces resilience of kelp beds to climate-driven catastrophic phase shift. Proc Natl Acad Sci USA 106: 22341-22345

> Loflen CL, Hovel KA (2010) Behavioral responses to variable predation risk in the California spiny lobster Panulirus interruptus. Mar Ecol Prog Ser 420:135-144

Neilson DJ, Buck T, Read R (2009) A comparison of catch rate between a traditional, basket-style hoop net and a rigid, conical-style hoop net used in the California lobster fishery. Calif Fish Game 95:53-61

Pederson HG, Johnson CR (2006) Predation of the sea urchin Heliocidaris erythrogramma by rock lobsters (Jasus edwardsii) in no-take marine reserves. J Exp Mar Biol Ecol 336:120-134

Pondella DJ II, Allen LG (2008) The decline and recovery of four predatory fishes from the Southern California Bight. Mar Biol 154:307-313

> Pyke GH, Pulliam HR, Charnov EL (1977) Optimal foraging: selective review of theory and tests. Q Rev Biol 52: 137-154

Rassweiler A, Schmitt RJ, Holbrook SJ (2010) Triggers and maintenance of multiple shifts in the state of a natural community. Oecologia 164:489-498

Rassweiler A, Costello C, Siegel DA (2012) Marine protected areas and the value of spatially optimized fishery management. Proc Natl Acad Sci USA 109:11884-11889

Rassweiler A, Costello C, Hilborn R, Siegel DA (2014) Inte- grating scientific guidance into marine spatial planning. Proc R Soc Lond B Biol Sci 281:20132252

Roth JD, Marshall JD, Murray DL, Nickerson DM, Steury TD (2007) Geographical gradients in diet affect population dynamics of Canada lynx. Ecology 88:2736-2743

Sale PF, Cowen RK, Danilowicz BS, Jones GP and others (2005) Critical science gaps impede use of no-take fishery reserves. Trends Ecol Evol 20:74-80

Shears NT, Babcock RC (2002) Marine reserves demonstrate top-down control of community structure on temperate reefs. Oecologia 132:131-142

- Shears NT, Babcock RC (2003) Continuing trophic cascade effects after 25 years of no-take marine reserve protection. Mar Ecol Prog Ser 246:1-16

Sih A, Christensen B (2001) Optimal diet theory: When does it work, and when and why does it fail? Anim Behav 61: 379-390

Smith MD, Wilen JE (2003) Economic impacts of marine reserves: the importance of spatial behavior. J Environ Econ Manag 46:183-206

Stephens DW, Krebs JR (1986) Foraging theory. Princeton University Press, Princeton, NJ

Stewart NL, Konar B (2012) Kelp forests versus urchin barrens: alternate stable states and their effect on sea otter prey quality in the Aleutian Islands. J Mar Biol 2012: 492308

> Steyn E, Schleyer MH (2011) Movement patterns of the east coast rock lobster Panulirus homarus rubellus on the coast of KwaZulu-Natal, South Africa. NZ J Mar Freshw Res 45:85-101

Stiner MC (2002) Carnivory, coevolution, and the geographic spread of the genus Homo. J Archaeol Res 10: $1-63$

Strong DR (1992) Are trophic cascades all wet? Differentiation and donor-control in speciose ecosystems. Ecology 73:747-754

> Svanbäck R, Bolnick DI (2007) Intraspecific competition drives increased resource use diversity within a natural population. Proc R Soc Lond B Biol Sci 274:839-844

Takagi KK, Ono NN, Wright WG (2010) Interspecific variation in palatability suggests cospecialization of antipredator defenses in sea hares. Mar Ecol Prog Ser 416: 137-144

Tegner MJ, Dayton PK (1981) Population structure, recruitment and mortality of two sea urchins (Strongylocentrotus franciscanus and $S$. purpuratus) in a kelp forest. Mar Ecol Prog Ser 5:255-268

> Tegner MJ, Levin LA (1983) Spiny lobsters and sea urchins: analysis of a predator-prey interaction. J Exp Mar Biol Ecol 73:125-150

> Tetreault I, Ambrose RF (2007) Temperate marine reserves enhance targeted but not untargeted fishes in multiple no-take MPAs. Ecol Appl 17:2251-2267

Tinker MT, Bentall G, Estes JA (2008) Food limitation leads to behavioral diversification and dietary specialization in sea otters. Proc Natl Acad Sci USA 105:560-565

White JW, Scholz AJ, Rassweiler A, Steinback C and others (2013) A comparison of approaches used for economic analysis in marine protected area network planning in California. Ocean Coast Manag 74:77-89

> Withy-Allen KR, Hovel KA (2013) California spiny lobster (Panulirus interruptus) movement behaviour and habitat use: implications for the effectiveness of marine protected areas. Mar Freshw Res 64:359-371

Zeidberg LD, Butler JL, Ramon D, Cossio A, Stierhoff KL, 
Henry A (2012) Estimation of spawning habitats of market squid (Doryteuthis opalescens) from field surveys of eggs off central and southern California. Mar Ecol 33: 326-336
Zimmer-Faust RK, Case JF (1982) Odors influencing foraging behavior of the California spiny lobster, Panulirus interruptus, and other decapod crustacea. Mar Behav Physiol 9:35-58

\begin{abstract}
Appendix. Summary of sampling design showing the number of dives, the number of sea hares presented per dive and the number of dives in which at least 1 lobster was observed attacking a sea hare. The number of lobsters tested in each dive depended on the density of foraging lobsters and diving conditions, both of which varied substantially from night to night. The number of presentations per dive averaged 15 in the 3 reserves that always had attacking lobsters; 15 in the 1 reserve that showed no attack, and 13 in off-reserve dives, none of which showed attack. Thus, there was no systematic bias in the number of lobsters that were offered sea hares at particular sites
\end{abstract}

\begin{tabular}{|lcccc|}
\hline Site & Reserve status & $\begin{array}{c}\text { No. of } \\
\text { dives }\end{array}$ & $\begin{array}{c}\text { No. of presen- } \\
\text { tations dive }\end{array}$ & $\begin{array}{c}\text { No. of dives } \\
\text { with attacks }\end{array}$ \\
\hline Big Fisherman Cove & Reserve & 12 & $9-22$ & 12 \\
& Off reserve & 3 & $12-16$ & 0 \\
Lulu Cove & Reserve & 5 & $12-26$ & 5 \\
Cathedral Cove & Off reserve & 3 & $10-20$ & 0 \\
Cavern Point & Reserve & 5 & $12-20$ & 5 \\
& Off reserve & 3 & $11-12$ & 0 \\
& Reserve & 4 & $10-20$ & 0 \\
& Off reserve & 3 & $10-14$ & 0 \\
\hline
\end{tabular}

Editorial responsibility: Janet Ley, St. Petersburg, Florida, USA
Submitted: July 7, 2014; Accepted: December 4, 2014 Proofs received from author(s): February 22, 2015 